\title{
ELEVATED TEMPERATURE INDUCED CHANGE OF NON- POINT SOURCE POLLUTANTS IN PADDY WATER
}

\author{
HONG, S.-C. ${ }^{*}$ JANG, E. S. - CHOI, S.-K. - CHOI, D.-H. - HuR, S. O. \\ Climate Change \& Agroecology Division, National Institute of Agricultural Sciences \\ Wanju 55365, Republic of Korea \\ ${ }^{*}$ Corresponding author \\ e-mail: schongcb@korea.kr; phone: +82-63-238-2501; fax: +82-63-238-3823
}

(Received 14 $4^{\text {th }}$ Jan 2019; accepted $28^{\text {th }}$ Feb 2019)

\begin{abstract}
Higher temperature could induce biological effects in many areas of agriculture. The objective of this study is to investigate the effects of elevated temperature on nutrients and non-point source pollutants in paddy water and soil. Nitrogen and phosphorus were applied based on the recommended application amounts for rice cultivation and there was an unfertilized plot as a control. Paddy soils were flooded with distilled water in an incubator for eight weeks. Temperature treatments included ambient as a control, ambient plus $2^{\circ} \mathrm{C}$, and ambient plus $4^{\circ} \mathrm{C}$. Soil $\mathrm{NH}_{4}-\mathrm{N}$ content after elevated temperature treatment was high in sandy loam soil and soil $\mathrm{NO}_{3}-\mathrm{N}$ content after elevated temperature treatment was high in clay loam soil. Elevated temperatures induced increments of water total nitrogen (T-N) concentration for no chemical fertilization, standard fertilization, and standard fertilization $+100 \%$ in sandy loam soil. T-N concentration dissolved in distilled water in rice straw of ambient $+2^{\circ} \mathrm{C}$ temperature increased by $24 \%$ more than that of the control temperature treatment, and total phosphorus (T-P) concentration of ambient $+4^{\circ} \mathrm{C}$ temperature increased by $16 \%$. Thus, it was considered that water soluble T-N and T-P of rice residue could be released easily by rain from agricultural fields.
\end{abstract}

Keywords: higher temperature, nutrient, rice paddy, straw, water soluble nutrient

\section{Introduction}

The Special Report on Global Warming of $1.5^{\circ} \mathrm{C}$ (SR15) was approved on October 5, 2018 at the $48^{\text {th }}$ session of the Intergovernmental Panel on Climate Change (IPCC) held in Incheon, Republic of Korea. This IPCC report was prepared by 99 authors and editors from 40 countries from around the world, and it is based on over 6,000 scientific references. The key point of this special report is that human activity has induced about $1^{\circ} \mathrm{C}\left(0.8 \sim 1.2^{\circ} \mathrm{C}\right)$ global warming at present compared with pre-industrialization times; and, if the current speed of warming continues, the rise will be over $1.5^{\circ} \mathrm{C}$ in $2030 \sim 2052$. Also, global warming is different depending on region and time, and extreme weather changes were detected during global warming of $0.5^{\circ} \mathrm{C}$ to the present. In order to reduce global warming within $1.5^{\circ} \mathrm{C}$, carbon dioxide $\left(\mathrm{CO}_{2}\right)$ emissions should achieve net zero. Temperature is the most important factor affecting plant growth and yield and every biological process changes depending on temperature (Cross and Zuber, 1972; Yan and Hunt, 1999). Generally, the relationship between air temperature and soil temperature is positive (Groffman et al., 2009), increasing temperature lowers soil moisture (Brzostek et al., 2012), and net nitrogen mineralization was shown to increase depending on higher temperature in an incubation experiment (Pendall et al., 2004), or not (Niklinska et al., 1999). Elevated temperature increases nitrogen mineralization by $45 \% \sim 52 \%$ (Rustad et al., 1998) and net nitrification by 32\% (Bai et al., 2013). Higher temperature affects nitrogen leaching by increasing $\mathrm{NO}_{3}{ }^{-}$solubility and affects the frequency of soil freezing and thawing (Bai and Houlton, 2009). 
Nutrient input materials for crop cultivation are chemical fertilizers, cow manure compost, pig manure compost, and various types of organic compost. Leaching of total nitrogen (T-N) and total phosphorus (T-P) by runoff from cultivated land acts as a nonpoint pollution source when they move out of the agricultural water system. The amount of non-point pollution sources from rice paddy is estimated at $3 \mathrm{~kg} \cdot \mathrm{ha}^{-1}$ of nitrogen and 2 $\mathrm{kg} \cdot \mathrm{ha}^{-1}$ of phosphorus (Shin, 2001; Kim, 2008; Jung, 2013). Soil loss and muddy water from rain are the factors that most affect management of the aqua-ecosystem and water quality control for drinking water sources in an increasingly significant way.

In a higher temperature environment, there could be changes in the decomposition, uptake by crop, volatilization, and runoff of nutrient input materials for crop cultivation. Therefore, this study was conducted to investigate changes in rice cultivation water as a non-point pollutant source under an elevated temperature environment.

\section{Materials and Methods}

\section{Fertilization}

This study was conducted from June to November 2017 at the National Institute of Agricultural Sciences (NIAST) in Wanju (Lat 35.834, Lon 127.038), Republic of Korea. The soils used were sandy loam and clay loam. Treatment consisted of a control with no added chemical fertilizer, chemical fertilizer, and chemical fertilizer plus $100 \%$ increase of the chemical fertilizer. A $50 \mathrm{ml}$ plastic tube was filled with $40 \mathrm{~g}$ of soil, which was treated with chemical fertilizer and then distilled water was poured into the tube. The chemical properties of the soils used in this study are shown in Table 1.

Table 1. Chemical properties of soils used in this study

\begin{tabular}{|c|c|c|c|c|c|c|c|c|}
\hline \multirow{2}{*}{ Soil property } & \multirow{2}{*}{$\begin{array}{c}\text { pH } \\
(1: 5)\end{array}$} & \multirow{2}{*}{$\begin{array}{c}\text { EC } \\
(\mathrm{dS} / \mathbf{m})\end{array}$} & \multirow{2}{*}{$\begin{array}{c}\mathrm{OM} \\
(\mathrm{g} / \mathrm{kg})\end{array}$} & \multirow{2}{*}{$\begin{array}{c}\mathrm{Av} . \mathrm{P}_{2} \mathrm{O}_{5} \\
(\mathrm{mg} / \mathrm{kg})\end{array}$} & $\mathbf{C a}$ & Mg & $\mathbf{K}$ & $\mathbf{N a}$ \\
\hline & & & & & \multicolumn{4}{|c|}{ Ex. cations $\left(\mathrm{Cmol}^{+} / \mathbf{k g}\right)$} \\
\hline Sandy loam & 6.8 & 0.74 & 4 & 54 & 1.3 & 3.7 & 0.54 & 1.49 \\
\hline Clay loam & 6.5 & 0.53 & 22 & 82 & 4.3 & 1.8 & 0.35 & 0.13 \\
\hline
\end{tabular}

\section{Temperature treatment}

The weather data used for the elevated temperature manipulation was provided by the Buraeing weather station located in Buraeing-myeon, Kimje-si, Jeonbuk province.

In order to calculate the day temperature treatment, the average maximum temperatures from July to September over a ten-year period (2007 2016) were calculated; and to calculate the night temperature treatment, the average minimum temperatures from July to September over a ten-year period (2007 2016) were calculated.

Temperature treatment was conducted from May 23, 2017 for eight months using an incubator. Temperature treatment with the incubator was over ten steps a day for 144 minutes each. Day and night temperatures of the ambient were $25^{\circ} \mathrm{C} / 18^{\circ} \mathrm{C}$, ambient + $2^{\circ} \mathrm{C}$ were $27^{\circ} \mathrm{C} / 20^{\circ} \mathrm{C}$, and ambient $+4^{\circ} \mathrm{C}$ were $29^{\circ} \mathrm{C} / 22^{\circ} \mathrm{C}$, respectively (Table 2). 
Table 2. Elevated temperature treatment in this study at each time by using an incubator

\begin{tabular}{c|c|c|c}
\hline $\begin{array}{c}\text { Time } \\
\text { (hour : minute) }\end{array}$ & Ambient & Ambient $+\mathbf{2}^{\mathbf{}} \mathbf{C}$ & Ambient $+\mathbf{4}^{\mathbf{}} \mathbf{C}$ \\
\hline $01: 44$ & 18 & 20 & 22 \\
$04: 08$ & 17 & 19 & 21 \\
$06: 32$ & 19 & 21 & 23 \\
$08: 56$ & 19 & 21 & 23 \\
$11: 20$ & 24 & 26 & 29 \\
$13: 44$ & 26 & 28 & 30 \\
$16: 08$ & 26 & 28 & 30 \\
$18: 32$ & 25 & 27 & 29 \\
$20: 56$ & 24 & 26 & 28 \\
$23: 20$ & 19 & 21 & 23 \\
\hline
\end{tabular}

\section{Sampling and analysis}

Soil $\mathrm{pH}$ and EC were measured by using a $\mathrm{pH}$ meter (Model 720A, Orion) and an EC meter (Model 145A, Orion). $\mathrm{NH}_{4}-\mathrm{N}$ concentration of soil was measured by the indophenol-blue method, $\mathrm{NO}_{3}-\mathrm{N}$ concentration of soil was measured by the chromotropic acid method, and available phosphorus concentration of soil was measured by the Lancaster method (RDA, 2010). For analysis of nutrient content, $80 \mathrm{ml}$ of distilled water was added to $40 \mathrm{~g}$ of soil, and the treated water was analysed every two weeks for a total of 4 times on June 6, June 20, July 4, and July 18.

In order to analyse the amount of T-N and T-P concentration of straw leachate in response to elevated temperature, $2 \mathrm{~g}$ of straw was soaked with $70 \mathrm{ml}$ of distilled water, and then after 1, 3, 5, and 7 days the water was sampled. T-N concentrations were measured by using a chromotropic acid method kit (C-mac, Korea) at $410 \mathrm{~nm}$, and T-P concentrations were measured by using a molybdovanadate method kit (C-mac, Korea) at $420 \mathrm{~nm}$.

\section{Results and Discussion}

\section{Soil Nitrogen}

Accumulated $\mathrm{NH}_{4}-\mathrm{N}$ concentration was determined every two weeks in soil applied with chemical fertilizer under elevated temperature. The results (Figure 1) show that the $\mathrm{NH}_{4}-\mathrm{N}$ concentration of no fertilization and standard fertilization treatment with ambient $+2^{\circ} \mathrm{C}$ and ambient $+4^{\circ} \mathrm{C}$ treatment was higher than that with the control temperature treatment in sandy loam soil. The $\mathrm{NH}_{4}-\mathrm{N}$ concentration of no fertilization with ambient $+2^{\circ} \mathrm{C}$ and ambient $+4^{\circ} \mathrm{C}$ treatment was higher than that with the control temperature treatment in clay loam soil.

The $\mathrm{NH}_{4}-\mathrm{N}$ concentration of standard fertilization and standard fertilization $+100 \%$ with ambient $+2^{\circ} \mathrm{C}$ and ambient $+4^{\circ} \mathrm{C}$ treatment was lower than the control temperature treatment in clay loam soil.

Also, the $\mathrm{NH}_{4}-\mathrm{N}$ concentration of no fertilization and standard fertilization was higher in sandy loam than in clay loam soil with an elevated temperature (ambient $+2^{\circ} \mathrm{C}$ and ambient $+4^{\circ} \mathrm{C}$ treatment). 


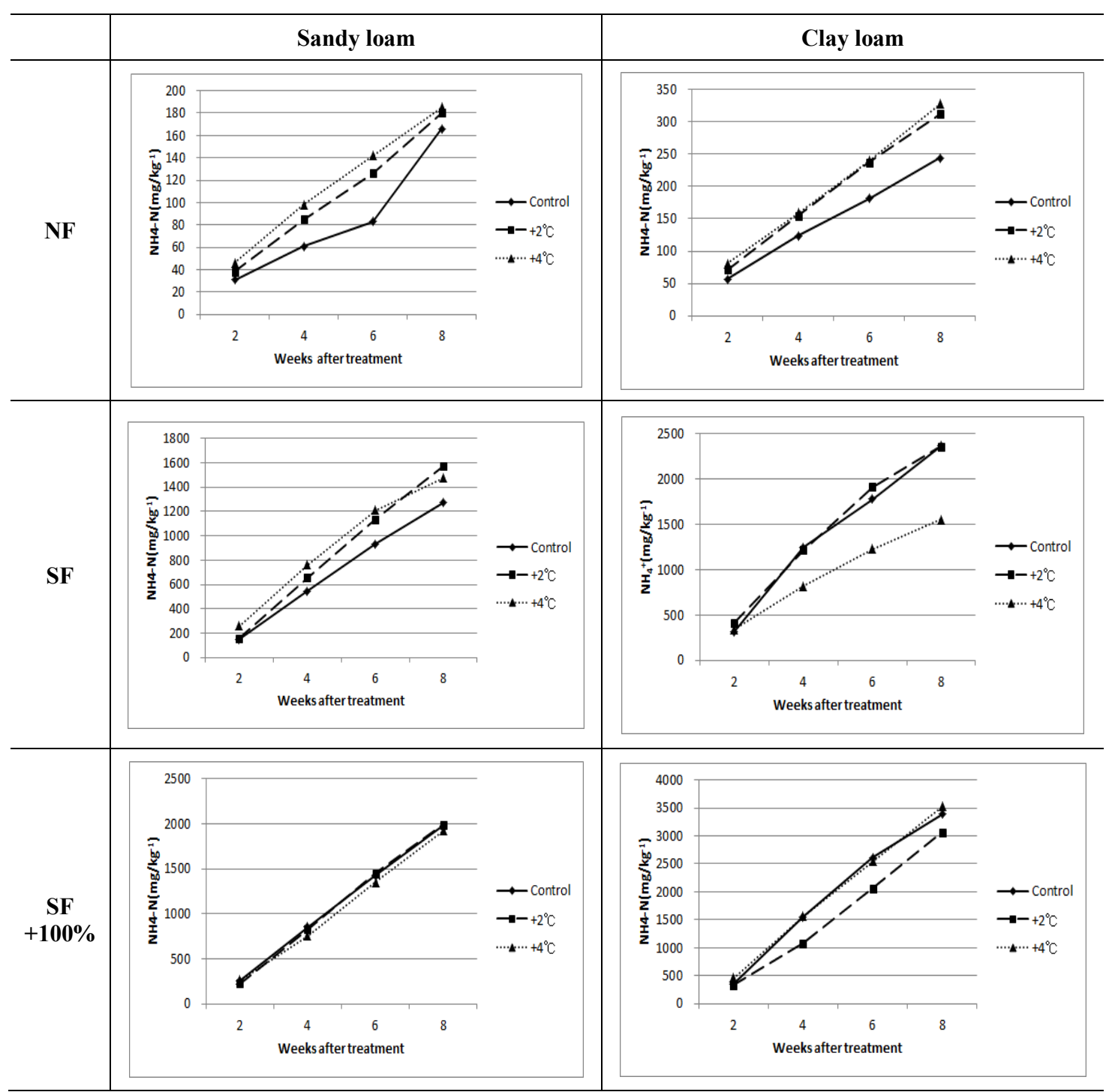

Figure 1. Concentration of NH4-N of soil treated with elevated temperature for 8 weeks, NF: No fertilization, SF: Standard fertilization, SF + $100 \%$ : Standard fertilization plus 100 percent increase

Accumulated $\mathrm{NO}_{3}-\mathrm{N}$ concentration was determined every two weeks in soil with applied chemical fertilizer under elevated temperature. The results (Figure 2) show that the $\mathrm{NO}_{3}-\mathrm{N}$ concentration of no fertilization treatment in ambient $+2{ }^{\circ} \mathrm{C}$ and ambient + $4{ }^{\circ} \mathrm{C}$ was higher than that with the control temperature treatment in sandy loam soil. The $\mathrm{NO}_{3}-\mathrm{N}$ concentration of standard fertilization treatment in ambient $+4^{\circ} \mathrm{C}$ was higher than that of the control temperature treatment in sandy loam soil.

The $\mathrm{NO}_{3}-\mathrm{N}$ concentration of no fertilization, standard fertilization, standard fertilization $+100 \%$ under ambient $+2^{\circ} \mathrm{C}$ and ambient $+4^{\circ} \mathrm{C}$ was higher than that of the control temperature treatment in clay loam soil.

Rustad et al. (2001) reported that elevated temperature increases soil net mineralization by $45 \% \sim 52 \%$, and Bai et al. (2013) reported that elevated temperature increases net nitrification by $32 \%$. Rising temperature increase the availability of $\mathrm{NO}_{3}-\mathrm{N}$ and affects nitrogen leaching by changing the frequency of soil freezing and thawing (Bai and 
Houlton, 2009). Through various incubation experiments, net nitrogen mineralization increased in relation to increasing temperature (Pendall et al., 2004), or not (Niklinska et al., 1999).

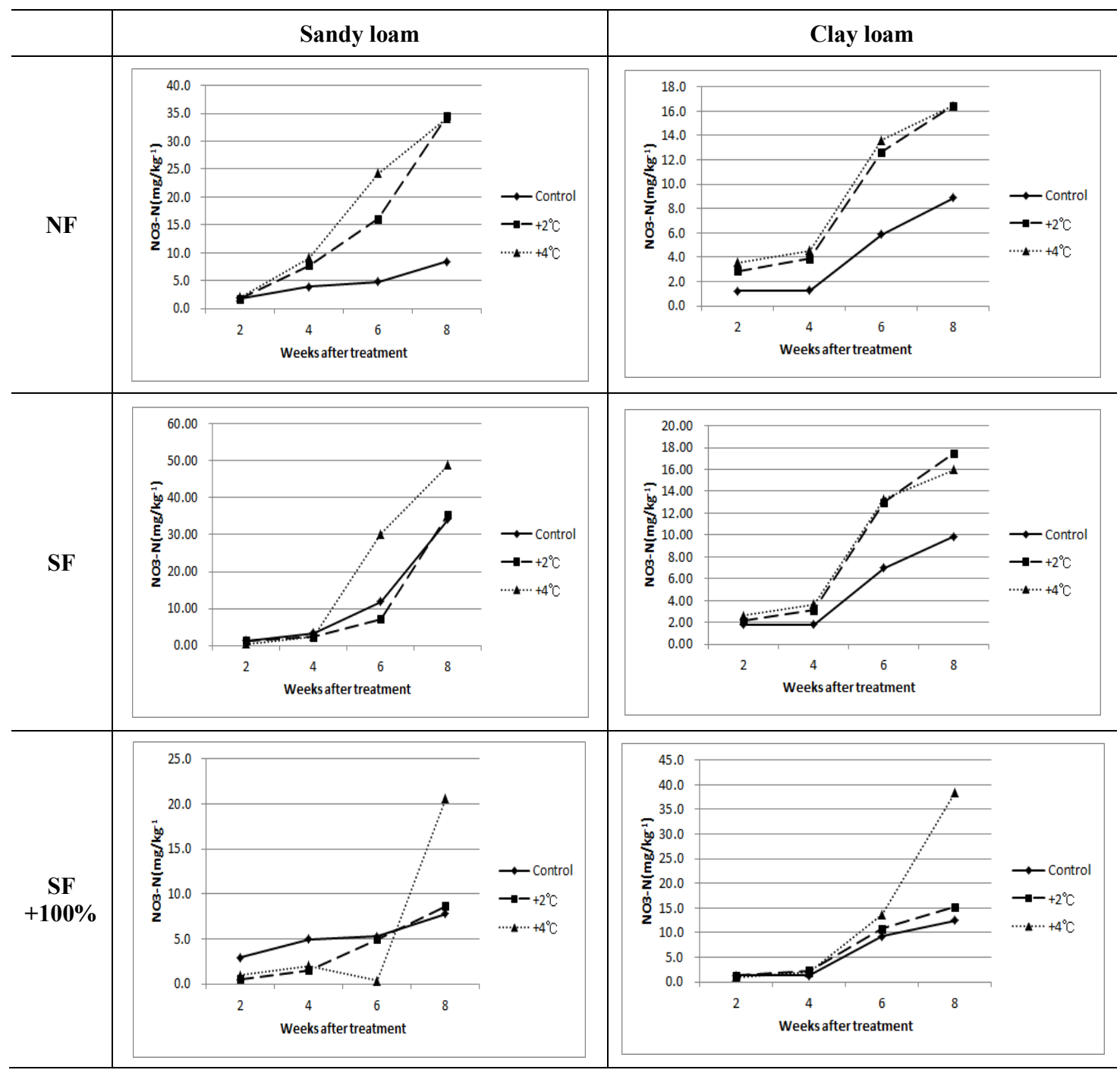

Figure 2. Concentration of NO3-N of soil treated with elevated temperature for 8 weeks, NF: No fertilization, SF: Standard fertilization, SF + $100 \%$ : Standard fertilization plus 100 percent increase

\section{Nitrogen, Phosphorus of Water}

In an elevated temperature environment, accumulated $\mathrm{T}-\mathrm{N}$ concentration was determined every two weeks in soil water treated with chemical fertilizer. The results (Figure 3) show that elevated temperature induced T-N concentration increases with no chemical fertilizer treatment, standard fertilization, and standard fertilization $+100 \%$ in sandy loam soil. Elevated temperature showed a T-N concentration increase only with standard fertilization in clay loam soil.

These results are similar to results from research showing that nitrification is activated by up-regulated soil temperature treatment (Verburg et al., 1999), nitrogen mineralization 
and amount of nitrification increase in relation to time at a depth of $15 \sim 30 \mathrm{~cm}$, and nitrogen mineralization and amount of nitrification are greater at the surface soil layer than the deep soil layer (Shin and Reddy, 1997). Also, Saad and Conrad (1993) reported that $25 \sim 30^{\circ} \mathrm{C}$ was the optimal temperature range for nitrification and denitrification in a microbial experiment.

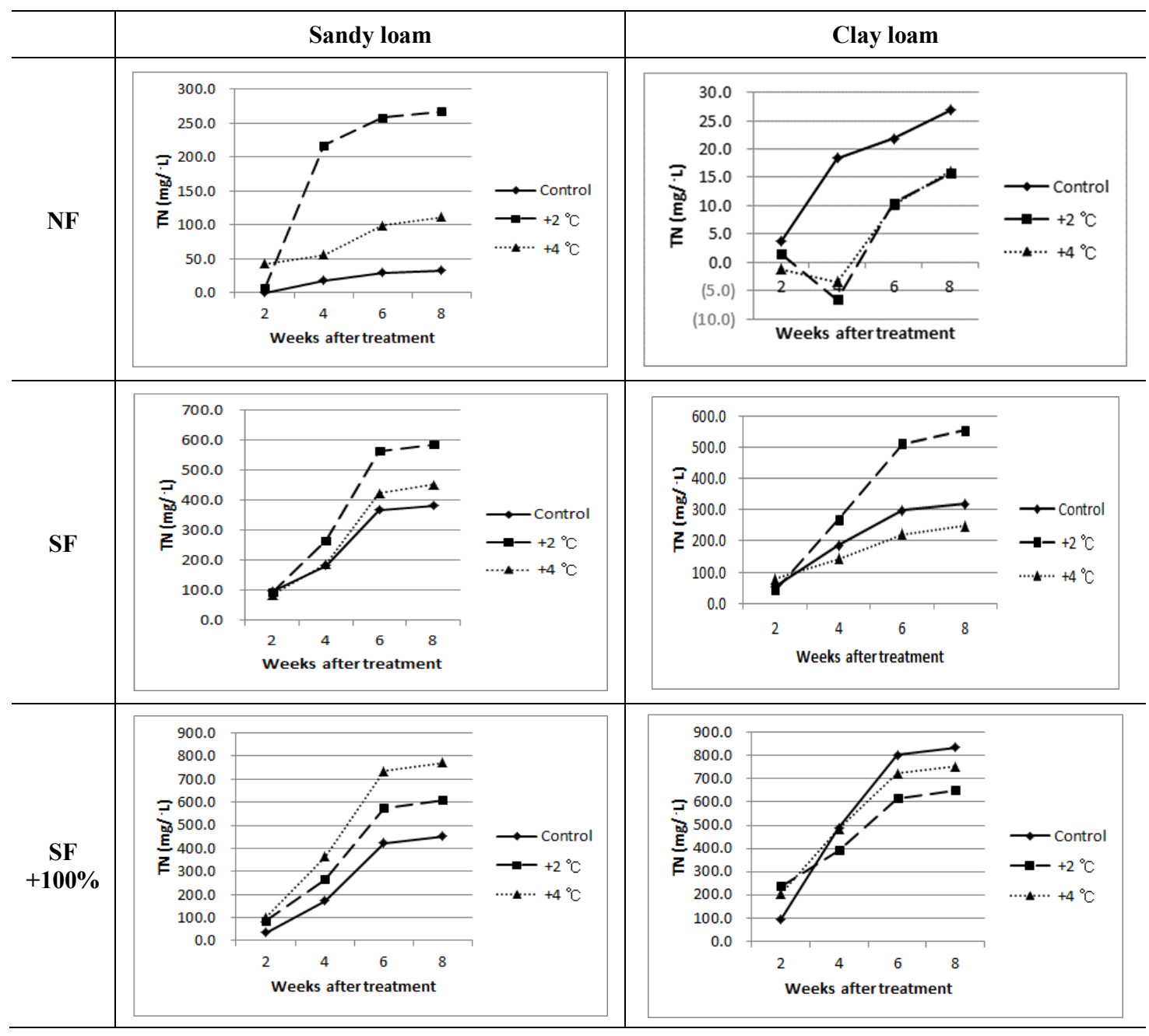

Figure 3. Concentration of total nitrogen (T-N) of water treated with elevated temperature for 8 weeks. NF: No fertilization, SF: Standard fertilization, SF + $100 \%$ : Standard fertilization plus 100 percent increase

In an elevated temperature environment, accumulated T-P concentration was determined every two weeks in soil water treated with chemical fertilizer. The results (Figure 4) show that elevated temperature treatment of ambient $+2^{\circ} \mathrm{C}$ and ambient $+4^{\circ} \mathrm{C}$ with no fertilization treatment increased T-P in sandy soil, but no such tendency was shown for T-P content of water in clay loam soil.

\section{Nutrient leaching of straw}

The accumulated nutrient concentration of leachate from straw was determined after treatment in an elevated temperature environment for seven days. The results (Figure 5) 
show that T-N concentration with the control temperature treatment was $3.2 \mathrm{mg} / \mathrm{L}^{-1}$, while that with the ambient $+2^{\circ} \mathrm{C}$ treatment was $4.0 \mathrm{mg} / \mathrm{L}^{-1}$, an increase of $24 \%$.

T-P concentration with the control temperature treatment was $3.4 \mathrm{mg} / \mathrm{L}^{-1}$, while that with the ambient $+4^{\circ} \mathrm{C}$ treatment was $4.1 \mathrm{mg} / \mathrm{L}^{-1}$, an increase of $16 \%$.

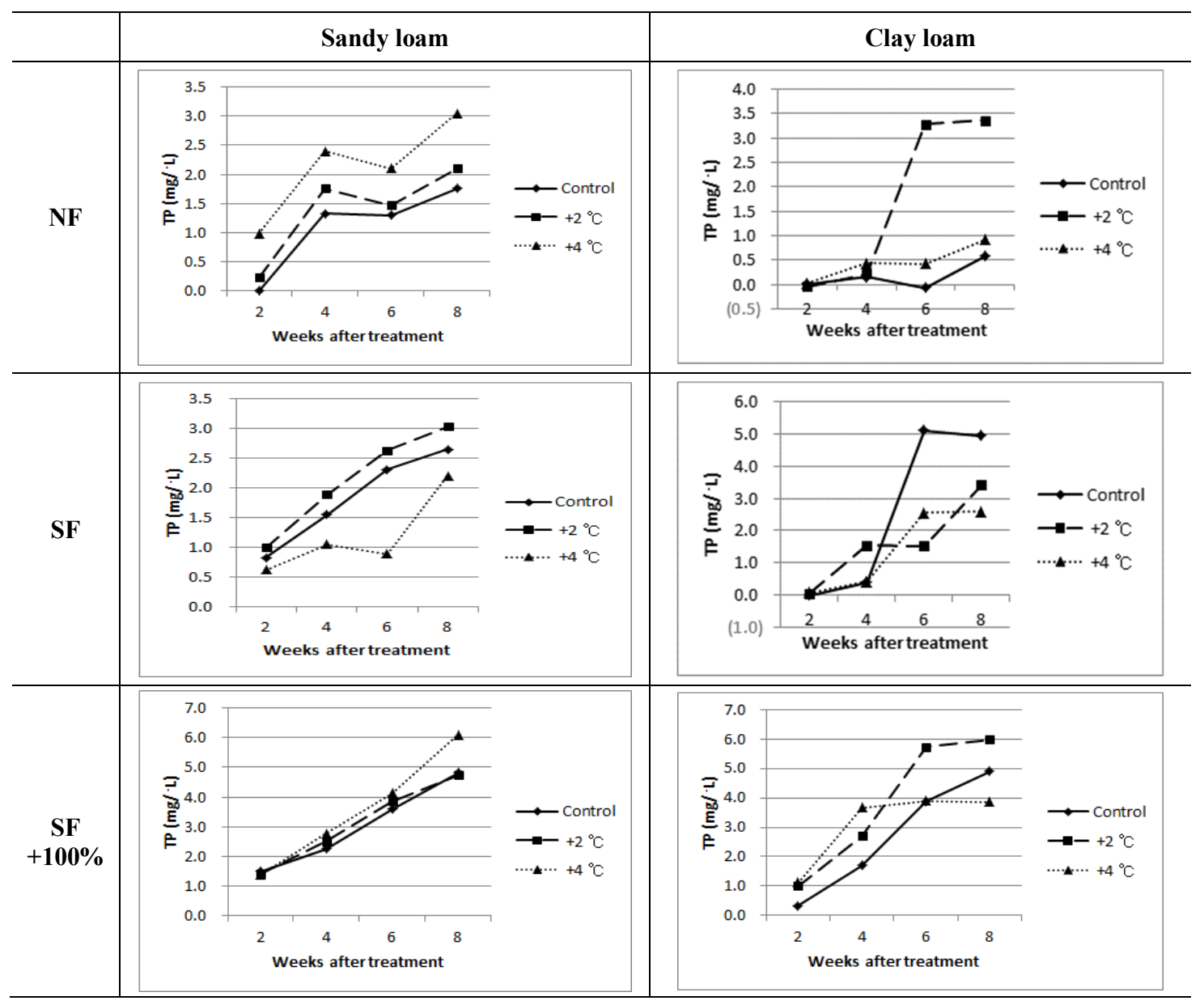

Figure 4. Concentration of total phosphorus (T-P) of water treated with elevated temperature for 8 weeks. NF: No fertilization, SF: Standard fertilization, SF + $100 \%$ : Standard fertilization plus 100 percent increase

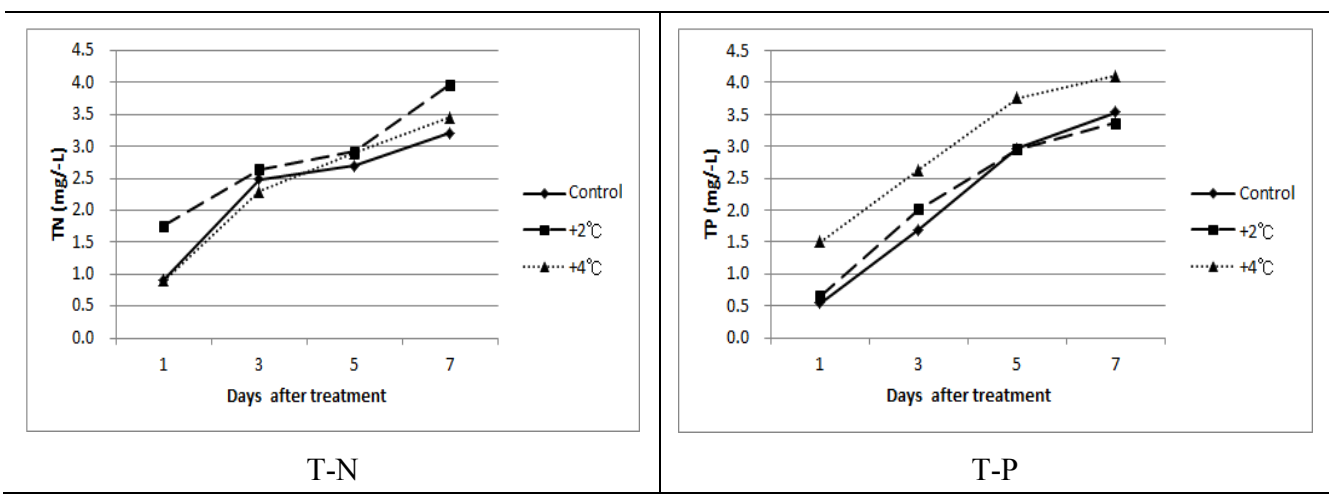

Figure 5. Concentration of T-N and T-P eluted from straw soaked in distilled water for seven days at three different temperatures 
Cowen and Lee reported (1973) that 5.4\% of total phosphorus of oak tree leaves was soluble and elutable. Schreeg (2013) reported that there is a relationship between solubility and tropical tree leaf amount with $\mathrm{r}^{2}=0.79$ for $\mathrm{K}, \mathrm{r}^{2}=0.51$ for $\mathrm{Na}$, and $\mathrm{r}^{2}=$ 0.66 for $\mathrm{P}$ with the weakest relationship of $\mathrm{r}^{2}=0.36$ for $\mathrm{N}$. Additionally, when total $\mathrm{K}$ content was 100 , that of $\mathrm{P}$ was $35 \%, \mathrm{Na} 28 \%$, and $\mathrm{N} 5 \%$. The mineral content of straw was reported to be $0.71 \%$ for T-N and $0.16 \%$ for $\mathrm{P}_{2} \mathrm{O}_{5}$ with the T-N and T-P of straw leached well in water; the longer the soaking of the straw, the higher the T-P concentration in the water (Hong, 2016). Hong et al. (2015) also reported that when red pepper furrows were covered with straw, the solubility of phosphorus in rain water led to excess runoff of phosphorus from uplands.

Therefore, under the elevated temperature environment in future in comparison with the current climate, more leaching of soluble nitrogen and phosphorus from crop residues and runoff from crop land can be expected.

\section{Conclusion}

Elevated temperatures induced increments of water total nitrogen $(\mathrm{T}-\mathrm{N})$ concentration for no chemical fertilization, standard fertilization, and standard fertilization $+100 \%$ in sandy loam soil. Under the elevated temperature environment in future in comparison with the current climate, more leaching of soluble nitrogen and phosphorus from crop residues and runoff from crop land can be expected. These results can be used as the basis for the development of technology in response to climate change that can reduce nutrient runoff and improve water quality at the watershed. There is a need for paddy field scale experiments under a near natural environment for factors such as temperature, precipitation, sunlight, humidity, and wind by using a practically scaled open-top chamber.

Acknowledgements. This study was carried out with the support of the "Research Program for Agricultural Science \& Technology Development (Project No. PJ012546)" of the National Institute of Agricultural Sciences, Rural Development Administration, Republic of Korea.

\section{REFERENCES}

[1] Bai, E., Houlton, B. Z. (2009): Coupled isotopic and process-based modeling of gaseous nitrogen losses from tropical rain forests. - Global Biogeochemical Cycles 23: doi: 10.1029/2008GB003361.

[2] Bai, E., Li, S., Xu, W., Li, W., Dai, W., Jiang, P. (2013): A meta-analysis of experimental warming effects on terrestrial nitrogen pools and dynamics. - New Phytol. 199 : 441-451.

[3] Brzostek, E. R., Blair, J. M., Dukes, J. S., Frey, S. D., Hobbie, S. E., Melillo, J. M., Mitchell, R. J., Pendall, E., Reich, P. B., Shaver, G. R. (2012): The effect of experimental warming and precipitation change on proteolytic enzyme activity: positive feedbacks to nitrogen availability are not universal. - Global Change Biology 18: 2617-2625.

[4] Cowen, W. F., Lee, G. F. (1973): Leaves as source of phosphorus. - Environmental Science \& Technology 7(9): 8539-8540.

[5] Cross, H. Z., Zuber, M. S. (1972): Prediction of flowering dates in maize based on different methods of estimating thermal units. - Agronomy journal 64: 351-355.

[6] Groffman, P., Butterbach-Bahl, K., Fulweiler, R., Gold, A., Morse, J., Stander, E.,Tague, C., Tonitto, C., Vidon, P. (2009): Challenges to incorporating spatially and temporally 
explicit phenomena (hotspots and hot moments) in denitrification models. Biogeochemistry 93: 49-77.

[7] Hong, S. C., Kim, M. K., Jung, G. B., So, K. H. (2016): Furrow covering effects with rice straw on nutrient discharge from upland soil used for red pepper cultivation. - Journal of the Korea Organic Resource Recycling Association 24(1): 11-19.

[8] Joung, D. S., Reddy, G. B. (1997): Nitrogen mineralization and nitrification of selected piedmont soils in north carolina. - Korean Journal of Soil Sciences and fertilizer 30(1): 2328.

[9] Jung, C. G., Ahn, S. R., Kim, S. J., Yang, H. J., Lee, H. J., Park, G. A. (2013): HSPF and SWAT modelling for identifying runoff reduction effect of non-point source pollution by rice straw mulching on upland crops. - Journal of Korean Society of Agricultural Engeenering 55(2): 47-57.

[10] Kim, J. H., Han, K. H., Lee, J. S. (2008): Characteristics of agricultural non-point source pollutants by rainfall events in rural watersheds. - Journal of Korean Society of Agricultural Engeenering 24(1): 69-77.

[11] Methods of Soil Chemical Analysis. 2010. p.68-85. NIAST. RDA.

[12] Niklinska, M., Maryanski, M., Laskowski, R. (1999): Effect of temperature on humus respiration rate and nitrogen mineralization: implications for global climate change. Biogeochemistry 44: 239-257.

[13] Pendall, E., Bridgham, S., Hanson, P. J., Hungate, B., Kicklighter, D. W., Johnson, D. W., Law, B. E., Luo, Y., Megonigal, J. P., Olsrud, M. (2004): Below-ground process responses to elevated $\mathrm{CO}_{2}$ and temperature: a discussion of observations, measurement methods, and models. - New Phytologist 162: 311-322.

[14] Rustad, L. E., Fernandez, I. J. (1998): Experimental soil warming effects on $\mathrm{CO}_{2}$ and $\mathrm{CH}_{4}$ flux from a low elevation spruce-fir forest soil in Maine, USA. - Global Change Biology 4: 597-605.

[15] Saad, O. A. L. O., Conrad, R. (1993): Temperature dependence of nitrification, denitrification, and turnover of nitric oxide in different soils. - Biology and Fertility of Soils 15: 21-27.

[16] Saxe, H., Cannell, M. G. R., Johnsen, Ø., Ryan, M. G., Vourlitis, G. (2001): Tree and forest functioning in response to global warming. - New Phytologist 149: 369-399.

[17] Schreeg, L. A., Mack, M. C., Turner, B. L. (2013): Nutrient-specific solubility patterns of leaf litter across lowland tropical woody species. - The Ecological Society of America 94(1): 94-105.

[18] Shin, E. S., Choi, J. Y., Lee, D. H. (2001): Characteristics of non-point source pollutants in surface runoff from rural area. - Journal of Korean Society of Water Quality 17(3): 299311.

[19] Verburg, P. S. J., Van Loon, W. K. P., Lukewille, A. (1999): The CLIMEX soil-heating experiment: soil response after 2 years of treatment. - Biology and Fertility of Soils 28: 271-276.

[20] Yan, W., Hunt, L. A. (1999): An Equation for modeling the temperature response of plants using only the cardinal temperature. Ann Bot. 84: 607-614. 